Case Commentary:

Manitoba Métis Federation v. Canada and Manitoba

\author{
Darren O’Toole \\ Faculty of Law, University of Ottawa
}

aboriginal policy studies Vol. 3, no. 1\&2, 2014, pp. 178-187

This article can be found at:

http://ejournals.library.ualberta.ca/index.php/aps/article/view/21704

ISSN: $1923-3299$

Article DOI: http://dx.doi.org/10.5663/aps.v3i1-2.21704

aboriginal policy studies is an online, peer-reviewed and multidisciplinary journal that publishes original, scholarly, and policy-relevant research on issues relevant to Métis, non-status Indians and urban Aboriginal people in Canada. For more information, please contact us at apsjournal@ualberta.ca or visit our website at www.ualberta.ca/nativestudies/aps/.

UNIVERSITY OF ALBERTA

FACULTY OF NATIVE STUDIES

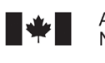




\title{
Case Commentary: Manitoba Métis Federation v. Canada and Manitoba
}

\author{
Darren O’Toole \\ Faculty of Law, University of Ottawa
}

Some 142 years after the adoption of the Manitoba Act, 1870, the Supreme Court of Canada came down with a decision in the Manitoba Métis Federation v. Canada and Manitoba, a case that revolved around the land clauses in the Act. When the District of Assiniboia-often known as the Red River Settlement-entered Confederation as the Province of Manitoba in 1870 under the terms of the Manitoba Act, sections 30 and 33 contained an anomaly relative to both earlier and later British colonies that were to form the provinces of Canada:

30. All ungranted or waste lands in the Province shall be, from and after the date of the said transfer, vested in the Crown, and administered by the Government of Canada for the purposes of the Dominion, subject to, and except and so far as the same may be affected by, the conditions and stipulations contained in the agreement for the surrender of Rupert's Land by the Hudson's Bay Company to Her Majesty.

33. The Governor General in Council shall from time to time settle and appoint the mode and form of Grants of Land from the Crown, and any Order in Council for that purpose when published in the Canada Gazette, shall have the same force and effect as if it were a portion of this Act.

Contrary to sections 92(5), 109, and 117, as well as the Third Schedule of the Constitution Act, 1867, s. 30 of the Manitoba Act provided that "All ungranted or waste lands" fell under the Crown in the right of Canada, and not of Manitoba. This anomaly was not to be resolved until the Constitution Act, 1930. Meanwhile, by way of compensation, the Manitoba Act contained two further clauses that concerned two types of land claims: the Indigenous title of the Métis and the quieting of existing titles.

31. And whereas, it is expedient, towards the extinguishment of the Indian Title to the lands in the Province, to appropriate a portion of such ungranted lands, to the extent of one million four hundred thousand acres thereof, for the benefit of the families of the half-breed residents, it is hereby enacted, that, under regulations to be from time to time made by the Governor General in Council, the LieutenantGovernor shall select such lots or tracts in such parts of the Province as he may deem expedient, to the extent aforesaid, and divide the same among the children of the half-breed heads of families residing in the Province at the time of the said transfer to Canada, and the same shall be granted to the said children respectively, in such mode and on such conditions as to settlement and otherwise, as the Governor General in Council may from time to time determine. 
32. For the quieting of titles, and assuring to the settlers in the Province the peaceable possession of the lands now held by them, it is enacted as follows:

(1) All grants of land in freehold made by the Hudson's Bay Company up to the eighth day of March, in the year 1869, shall, if required by the owner, be confirmed by grant from the Crown.

(2) All grants of estates less than freehold in land made by the Hudson's Bay Company up to the eighth day of March aforesaid, shall, if required by the owner, be converted into an estate in freehold by grant from the Crown.

(3) All titles by occupancy with the sanction and under the license and authority of the Hudson's Bay Company up to the eighth day of March aforesaid, of land in that part of the Province in which the Indian Title has been extinguished, shall, if required by the owner, be converted into an estate in freehold by grant from the Crown.

(4) All persons in peaceable possession of tracts of land at the time of the transfer to Canada, in those parts of the Province in which the Indian Title has not been extinguished, shall have the right of pre-emption of the same, on such terms and conditions as may be determined by the Governor in Council.

(5) The Lieutenant-Governor is hereby authorized, under regulations to be made from time to time by the Governor General in Council, to make all such provisions for ascertaining and adjusting, on fair and equitable terms, the rights of Common, and rights of cutting Hay held and enjoyed by the settlers in the Province, and for the commutation of the same by grants of land from the Crown.

To further complicate the legal issues involved, the Manitoba Act, 1870 was subsequently constitutionally entrenched by the Constitution Act, $1871 .{ }^{1}$ While historians agree that very little of these lands every actually ended up in the hands of the "the half-breed heads of families" or their children, the main legal question is to what degree the federal government could be held responsible for the loss of land.

At trial, the Manitoba Métis Federation (MMF) sought declaratory relief: 1) that enactments (both statutes and orders in council) of the Parliament of Canada and the Legislature of Manitoba were unconstitutional or ultra vires; 2) that Canada failed to fulfil its obligations, properly or at all, to the Métis under sections 31 and 32 of the Act, and pursuant to the undertakings given by the Crown; 3) that Manitoba, by enacting certain legislation and by imposing taxes on lands referred to in sections 31 and 32 of the Act prior to the grant of those lands, unconstitutionally interfered with the fulfilment of the obligations under sections 31 and 32 of the Act; and 4) that there was a treaty made in

1 An Act respecting the establishment of Provinces in the Dominion of Canada, 1871, 34 and 35 Vict., c. 28. [Constitution Act, 1871] 
1870 between the Crown in the right of Canada and the Provisional Government and the people of Red River. ${ }^{2}$ When the trial judge, Alan D. MacInnes of the Manitoba Queen's Bench, rendered his decision in Manitoba Métis Federation v. Canada on 7 December 2007, he not only found against the plaintiff on all four counts, but even refused to grant the MMF standing. From the beginning, Justice MacInnes held that the relevant statutes of limitations applied as did the equitable doctrine of laches, which in itself decided the case. ${ }^{3}$ Nevertheless, he decided it was necessary to address the substantive issues.

In terms of s. 32, counsel for the MMF had attempted to treat sections 31 and 32 as part of a single land settlement scheme for the Métis as part of a larger "treaty" between the Crown and the Provisional Government. Quite predictably, Justice MacInnes arrived at the conclusion that the Manitoba Act is not a treaty, but an Act of Parliament. ${ }^{4}$ Before the Supreme Court of Canada, the MMF dropped the relief it was seeking relative to the status of the Manitoba Act as a treaty, although the Court confirmed the trial judge's conclusion of law that it was a constitutional provision and not a treaty. ${ }^{5}$ This allowed him to treat sections 31 and 32 as entirely separate legal questions. While the plaintiff argued that, because the majority of settlers were Métis, the Crown had a fiduciary duty toward them in regards to s. 32 lands and that the manner in which it was implemented breached the honour of the Crown. Justice MacInnes held that the "provisions of section 32 did not apply to the Métis as Métis, but it applied to all settlers. Its purpose had nothing to do with the aboriginality of the Métis, but was simply to quiet titles and assure the retention of lands by all residents [...]." ${ }^{\prime}$ Since s. 32 did not involve the ostensible surrender of Indigenous title, the legal issues did not raise questions of the honour of the Crown or a fiduciary duty on the part of the Crown toward the Métis as an Aboriginal people. In any event, Justice MacInnes found that no public law duty was breached on the part of the Crown during its implementation. ${ }^{7}$ The Manitoba Court of Appeal upheld the trial judge's conclusion in this regard. ${ }^{8}$ Likewise, the Supreme Court of Canada "agree[d] with the courts below that the s. 32 claim is not established, and [found] it unnecessary to consider the constitutionality of the implementing statutes." ${ }^{\prime 9}$ For this reason, I will limit the remainder of my commentary to the issues pertaining to s. 31 .

2 Manitoba Métis Federation v. Canada (Attorney General) and Manitoba (Attorney General), [2007] 223 Man. R. (2nd) 42, at para. 5. [MMF (MQB)]

3 Ibid., at paras. 447 and 460.

4 Ibid., at para. 510.

5 Manitoba Métis Federation v. Canada (Attorney General) and Manitoba (Attorney General), [2013] S.C.C. 14, at para. 93. [MMF (SCC)]

$6 M M F$, supra note 2 at para. 1170. (MQB)

7 Ibid. at para. 1206.

8 Ibid. at para. 620 .

$9 M M F$, supra note 5 at para. 10. (SCC) 
In terms of s. 31, Justice MacInnes started from the premise that "Parliament, as a matter of law, could not create aboriginal title because the essence of aboriginal title is that it existed before British Sovereignty." ${ }^{10}$ For the expression "Indian title" in s. 31 to mean anything, the Métis had to have an existing Indigenous title to surrender in 1870 . For this reason, Justice MacInnes considered it necessary to determine whether the Métis held Aboriginal title and applied the relevant Delgamuukw criteria for establishing Aboriginal title at law. Given that he established "effective control" as early as 1670 and no later than 1763, it was a foregone conclusion the Métis had no title to surrender as they quite simply did not even exist at that date. ${ }^{11}$ He then inquired as to whether the Métis were "Indians," 12 to which he responded in the negative. Since the Métis had no Aboriginal title, there could be no fiduciary duty owed to them on the part of the Crown. ${ }^{13}$ Since the notion of the honour of the Crown "arises out of the Crown's historic relationship with Indians who are vulnerable, uneducated people unfamiliar with European ways and the technical nature of language" and the Métis "were not a vulnerable or unsophisticated people"-in other words, they weren't "Indians" - the doctrine of the honour of the Crown had no relevance to the case. ${ }^{14}$

While Chief Justice Scott, for a unanimous five-member panel of the Manitoba Court of Appeal, essentially upheld the trial court's decision, he did fault the trial judge on at least three errors of law. First of all, Chief Justice Scott admonished his colleague somewhat when he wrote that, while "the trial judge found that the Métis were not Indians, the more relevant question is whether or not they are Aboriginal," and that the Court of Appeal had "implicitly recognized the Métis as Aboriginal peoples in Blais, an Aboriginal rights case in which s. 35 was not at issue," much like the case at bar. ${ }^{15}$ While Chief Justice Scott added that "nothing in [Justice MacInnes's] judgment questions their status as an Aboriginal people," the latter only mentioned once in his entire decision that the "Métis are an Aboriginal people under s. 35," ${ }^{16}$ and his "but" seems to imply that they have no existing Aboriginal rights. This also seems implicit when Chief Justice Scott found the trial judge erred for not recognizing an on-going overarching fiduciary Crown-Métis relationship, regardless of whether it gave rise to duties in the particular circumstances of the case at bar. ${ }^{17}$ This

$10 M M F$, supra note 2 at para. 652. (MQB)

11 Ibid. at para. 593.

$12 M M F$, supra note 2 at paras. 595-616. (MQB)

13 Ibid. at para. 631.

14 Ibid. at paras. 635, 641 and 646 .

15 Manitoba Métis Federation v. Canada (Attorney General) and Manitoba (Attorney General), [2010] 3 C.N.L.R. 233, at paras. 382 and 379. [MMF (MCA)]

$16 M M F$, supra note 2 at paras. 618. (MQB)

$17 M M F$, supra note 15 at para. 432. (MCA) 
leads to the second issue relative to the trial judge's assertion that no fiduciary duty could exist in the absence of Aboriginal title. Chief Justice Scott, however, found that "in order to establish a fiduciary obligation within the Crown-Aboriginal relationship, there must be a specific or cognizable Aboriginal interest" and not necessarily outright title. ${ }^{18}$ While the Court of Appeal upheld the trial judge's conclusion that any alleged breach of fiduciary duty was statute-barred and that declaratory relief, as equitable remedy, was defeated by the equitable doctrine of laches, it nevertheless found he erred insofar as he applied them to constitutional claims. While the Court found the question of the constitutionality of certain statutes of Manitoba was nonetheless defeated by the doctrine of mootness-the legislation in question was spent or repealed - this particular question of law was to prove pivotal in the Supreme Court's decision.

As there was no dissenting decision among the judges of the Manitoba Court of Appeal, the Supreme Court of Canada's decision to accept the appeal and overturn the decisions of both the Manitoba Queen's Bench and the Manitoba Court of Appeal was somewhat of an unexpected outcome. First of all, the Court rephrased the legal questions in the following manner: "The main issues are (1) whether Canada failed to act in accordance with its legal obligations, and (2) whether the Métis' claim is too late and thus barred by the doctrine of laches or by any limitations law [...]." 19 The first question involved a series of six subquestions:

1) Does the Manitoba Metis Federation have standing in the action?

2) Is Canada in breach of a fiduciary duty to the Métis?

3) Did Canada fail to comply with the honour of the Crown in the implementation of ss. 31 and 32 of the Manitoba Act?

4) Were the Manitoba statutes related to implementation unconstitutional?

5) Is the claim for a declaration barred by limitations?

6) Is the claim for a declaration barred by laches?

In regards to the first question, the Court overturned the lower court decisions and granted the MMF standing. On the score of the question of the Manitoba statutes, the Court upheld the Court of Appeal and simply stated, "they are moot. To consider their constitutionality would be a misuse of the Court's time. We therefore need not address this issue." 20

While the Court did not find that Canada was in breach of a fiduciary duty to the Métis, it did find it failed to comply with the honour of the Crown. Here, the Court seemed to build on Chief Justice Scott's comments that Justice MacInnes failed to acknowledge the existence

18 Ibid. at para. 472. (MCA)

$19 M M F$, supra note 5 at para. 8. (SCC)

20 Ibid. at para. 132. (SCC) 
of a fiduciary relationship between the Crown and the Métis. The Court indirectly criticized the trial judge's remarks concerning the source of fiduciary duties when it stated that the doctrine of the honour of the Crown "did not arise from a paternalistic desire to protect the Aboriginal peoples; rather, it was a recognition of their strength." ${ }^{21}$ In the Court's view, "the honour of the Crown requires it to act diligently in pursuit of its solemn obligations and the honourable reconciliation of Crown and Aboriginal interests." 22 Furthermore, the Court recalled that the honour of the Crown has been termed a "constitutional principle"23 and that "the honour of the Crown is engaged by constitutional obligations to Aboriginal groups. Section 31 of the Manitoba Act, 1870 is just such a constitutional obligation." 24 Furthermore, the Court recalled that "this Court has found that limitations of actions statutes cannot prevent the courts, as guardians of the Constitution, from issuing declarations on the constitutionality of legislation. By extension, limitations acts cannot prevent the courts from issuing a declaration on the constitutionality of the Crown's conduct." 25 Likewise, when it came to the doctrine of laches, the Court remarked that it "is difficult to see how a court, in its role as guardian of the Constitution, could apply an equitable doctrine to defeat a claim for a declaration that a provision of the Constitution has not been fulfilled as required by the honour of the Crown." ${ }^{26}$ As a question of law then, the Court upheld the Court of Appeal's conclusion that limitation periods and laches cannot preclude a constitutional document, but the Court applied this finding of law to both the principle to the honour of the Crown and s. 31.

Early in the decision, the Court remarked that it was "not disputed that there was considerable delay in implementing the constitutional provisions" 27 and notably cited both the trial judge's ${ }^{28}$ and the Court of Appeal's finding of fact to this effect. ${ }^{29}$ The Court also affirmed the trial judge's conclusion of law that the purpose of $s .31$ was to provide "families of the Métis through their children a head start in the new country in anticipation of the probable and expected influx of immigrants" 30 when it asserted that the "immediate purpose of the obligation was to give the Métis children a head start over the expected

21 Ibid. at para. 66.

22 Ibid. at para. 78 .

23 Ibid. at para. 69.

24 Ibid. at para. 91.

25 Ibid. at para. 135.

26 Ibid. at para. 153.

$27 \mathrm{MMF}$, supra note 5 at para. 8. (SCC)

28 Ibid. at para. 109, (SCC) citing MMF, supra note 2 at para. 1207. (MQB)

29 Ibid. at para. 106, (SCC) citing $M M F$, supra note 2 at para. 656. (MCA)

$30 \mathrm{MMF}$, supra note 2 at para. 655. (MQB) 
influx of settlers from the east." ${ }^{11}$ As the Court stated: "Time was then plainly of the essence, if the goal of giving the Métis children a real advantage, relative to an impending influx of settlers from the east, was to be achieved." ${ }^{2}$ However, the "broader purpose [of s. 31] was to reconcile the Métis' Aboriginal interests in the Manitoba territory with the assertion of Crown sovereignty [...]." ${ }^{33}$ Given that both these objectives could only be accomplished if s. 31 were implemented without delay, the Supreme Court concluded that these delays in the implementation of the s. 31 grant did not uphold the honour of the Crown, which requires the Crown to act diligently. ${ }^{34}$

The basis for the Court's decision, then, was that s. 31 constitutes "a constitutional obligation explicitly directed at an Aboriginal people"35 and not because it was dealing with an Aboriginal interest in land. And this is where the Court's decision is particularly disconcerting. The Court claimed that the "trial judge held that the Métis failed to establish a specific, cognizable interest in land." ${ }^{36}$ As we have seen, this is not what occurred. First of all, as we have seen, the trial judge held that the existence of Aboriginal title had to be established to give rise to a fiduciary duty, and the Court of Appeal found the trial judge had erred since what was necessary was a "cognitive Aboriginal interest" in land. By referring to a "specific or cognizable Aboriginal interest" in land, ${ }^{37}$ the Court affirmed the Court of Appeal's conclusion that the trial judge had erred at law. Second, it is misleading to claim that the Métis "failed to establish" a cognizable Aboriginal interest when they had never even attempted to argue it. They refused to argue common law Aboriginal title and instead relied on the expression "toward the extinguishment of Indian title" in s. 31 to establish their title. Before the Supreme Court of Canada, the appellant again argued "that the trial judge and the Court of Appeal erred in going behind the language of s. 31 and demanding proof of a collective Aboriginal interest in land." ${ }^{38}$ While this is true of the trial judge, Chief Justice Scott in fact commented that "focussed argument on whether or not this critical component of a fiduciary obligation existed has not taken place" and refused to decide the issue. ${ }^{39} \mathrm{He}$ explicitly left the question open when he remarked "it is possible that the Métis could have an interest in land sufficient to meet this particular requirement towards establishing a fiduciary duty." 40

$31 \mathrm{MMF}$, supra note 5 at para. 9. (SCC)

32 Ibid. at para.102. (SCC)

33 Ibid. at para. 9.

34 Ibid. at para. 128.

35 Ibid. at para. 72 .

36 Ibid. at para. 52 .

37 Ibid. at para. 51.

38 Ibid. at para. 57.

$39 \mathrm{MMF}$, supra note 15 at para. 509 (MCA)

40 Ibid. at 507. 
By affirming the trial judge's finding concerning both going behind the language of s. 31 and his conclusion concerning Métis Aboriginal title, the Supreme Court of Canada essentially upheld both his application of the Delgamuukw criteria and his assertion that "Parliament, as a matter of law, could not create aboriginal title." Again, despite the fact that he claimed to modify the cut-off date by which Aboriginal title must be proven to have existed from that of the "affirmation of sovereignty" (Delgamuukw) to "effective control" (Powley) criterion, Justice MacInnes held that in "1670, Britain made its extensive land grant to the $\mathrm{HBC}$ and from that date, in my view, Britain exercised control through the HBC in those areas where the grant pertained and beyond that after 1763." ${ }^{41}$ Now, it is common knowledge among fur-trade historians that the HBC only had a scanty six forts on the coast by 1717 and did not establish any inland until 1774 when competition from the North West Company forced it to. How could this constitute "effective control"? Surely, the trial judge made an error of law here.

In terms of the "dimensions" of Aboriginal title, the Court held in Delgamuukw that "it is held communally. Aboriginal title cannot be held by individual aboriginal persons; it is a collective right to land held by all members of an aboriginal nation." 42 In $M M F$, the Court specified that an Aboriginal people with an interest in land is "not sufficient to establish an Aboriginal interest in land. The interest [...] must be distinctly Aboriginal: it must be a communal Aboriginal interest in the land that is integral to the nature of the Métis distinctive community and their relationship to the land." 43 The Court then recalled the trial judge's finding of fact that "the Métis used and held land individually, rather than communally" and that their "ownership practices were incompatible with the claimed Aboriginal interest," 44 and concluded that "the trial judge's findings of fact that the Métis had no communal Aboriginal interest in land are fatal to this contention." 45 Furthermore, when the Court recalled that an "Aboriginal interest in land [...] cannot be established by treaty, or, by extension, legislation," 46 it essentially confirmed the trail judge's ruling that "Parliament, as a matter of law, could not create aboriginal title." 47

But just what is "Aboriginal title"? One thing the Court has established that it is not is Indigenous title. The very idea of a cognitive Aboriginal interest is that it is "cognitive"meaning that that is "recognizable" to the common law because it is analogous to a common

$41 M M F$, supra note 2 at para. 580 .

42 Delgamuukw v. British Columbia, [1997] 3 S.C.R. 1010, at para. 115.

43 Ibid. at para. 59. Emphasis added.

44 Ibid. at para. 56.

45 Ibid. at para. 59 .

46 Ibid. at para. 58 .

47 Ibid. at para. 652. 
law interest in land. An Indigenous interest in land is the interest - whether cognitive at law or not-that an Indigenous people attributes to itself or to a tribe, clan, family, or individual according to its particular Indigenous legal order. In Campbell v. Hall, Lord Mansfield recalled that "the laws of a conquered country continue in force, until they are altered by the conqueror." ${ }^{8}$ In Calder, Justice Hall added that "A fortiori the same principles [...] must apply to lands which become subject to British sovereignty by discovery or by declaration." 49 In Re Southern Rhodesia, Lord Sumner of the Judicial Committee of the Privy Council held in obiter that "there are indigenous peoples whose legal conceptions, though differently developed, are hardly less precise than our own. When once they have been studied and understood they are no less enforceable than rights arising under English law." ${ }^{50}$ In other words, the closer Indigenous interest in land is to a common law interest-i.e., individual and alienable-the easier it is for it to be cognizable at law. But this involves thoroughly studying the particular kinds of interests in land that exist within a specific Indigenous legal order. This was reaffirmed even more clearly in Amodu Tijani v. Secretary, Southern Nigeria, where Lord Haldane of the JCPC stated that, "in interpreting the native title to land $[. .$.$] much caution is essential. There is a tendency, operating at times unconsciously,$ to render that title conceptually in terms which are appropriate only to systems which have grown up under English law. But this tendency has to be held in check closely. [...] To ascertain how far this latter development of right has progressed involves the study of the history of the particular community and its usages in each case. Abstract principles fashioned a priori are of but little assistance, and are as often as not misleading." 51

Yet, this is exactly what the Court did in Delgammukw when it determined that Aboriginal title is necessarily collective and inalienable except to the Crown: it "fashioned abstract principles a priori" instead of limiting itself to studying "the history of the particular community and its usages in each case." The conundrum does not end there. In Delgamuukw, the Court recognized two sources of Aboriginal title: that of prior physical occupation, but more importantly "the relationship between common law and pre-existing systems of aboriginal law." 52 In Van der Peet, the Court stated that the purpose of s. 35 of the Constitution Act, 1982 is "the reconciliation of the pre-existence of aboriginal societies with the sovereignty of the Crown." ${ }^{53}$ Further on, Chief Justice Lamer for the majority added that "true reconciliation" involves taking "into account the perspective of the aboriginal people claiming the right," but that "that perspective must be framed in terms cognizable to

48 Campbell v. Hall [1774], 98 E.R. 1045, at 1047.

49 Calder v. British Columbia (Attorney-General), [1973] S.C.R. 313 at para. 113.

50 Re Southern Rhodesia [1919] A.C. 211, at 233. Emphasis added.

51 Amodu Tijani v. Secretary, Southern Nigeria [[1921] 2 A.C. 399], at pages 402 to 404. Emphasis added.

52 Delgamuиkw, supra note 42 at para. 114.

53 R. v. Van der Peet, [1996] 2 S.C.R. 507, at para. 31. 
the Canadian legal and constitutional structure." ${ }^{54}$ In terms of proof of occupancy, Chief Justice Lamer noted in Delgamuukw that "the Gitksan effectively take the position that aboriginal title arises from and should reflect the pattern of land holdings under aboriginal law." Again, Chief Justice Lamer repeated that "the source of aboriginal title appears to be grounded both in the common law and in the aboriginal perspective on land; the latter includes, but is not limited to, their systems of law." 55

In other words, "Aboriginal title" is not simply the outright reception of Indigenous title into the common law: it is a transmogrification. Not only is "Aboriginal" title "sui generis" relative to other real property rights in the common law, it is also sui generis relative to the original property interests within the Indigenous legal system that is its nominal source. This is made clear in Delgamuukw when Chief Justice Lamer specified that the dimension of "inalienability of aboriginal lands is, at least in part, a function of the common law principle that settlers in colonies must derive their title from Crown grant and, therefore, cannot acquire title through purchase from aboriginal inhabitants. It is also, again only in part, a function of a general policy 'to ensure that Indians are not dispossessed of their entitlements." 56 The implication is that so-called "Aboriginal title" may have little or nothing to do with property rights such as they are conceived of within a particular Indigenous legal system and is ipso facto a creature of the common law. One is left wondering why "Parliament, as a matter of law, cannot create Aboriginal title," when common law courts apparently can...

54 Ibid. at para. 49.

55 Delgamuukw, supra note 42 at para. 147.

56 Ibid. at para. 129. Emphasis added. 